\title{
MW-assisted Meyer-Schuster rearrangement of propargylic alcohols catalyzed by the oxovanadate complex $\left[\mathrm{V}(\mathrm{O}) \mathrm{Cl}(\mathrm{OEt})_{2}\right]$
}

\author{
Antonio Antiñolo, ${ }^{[a]}$ Fernando Carrillo-Hermosilla, ${ }^{\left[{ }^{[a]}\right]}$ Victorio Cadierno, ${ }^{[b]}$ Joaquín \\ García-Álvarez, ${ }^{*[b]}$ and Antonio Otero ${ }^{[a]}$
}

A general and efficient procedure for the selective Meyer-Schuster isomerization of both terminal and internal alkynols has been developed using catalytic amounts of the readily accessible oxovanadium $(\mathrm{V})$ complex $\left[\mathrm{V}(\mathrm{O}) \mathrm{Cl}(\mathrm{OEt})_{2}\right]$. Reactions proceeded smoothly in toluene at $80{ }^{\circ} \mathrm{C}$, under microwave-irradiation, to provide the corresponding $\alpha, \beta$-unsaturated carbonyl compounds in excellent yields and short times without the assistance of any additive.

\section{Introduction}

$\alpha, \beta$-Unsaturated carbonyl compounds are useful building blocks in organic synthesis, advanced intermediates in the manufacture of aromes and fragrances, and key structural units in a large number of biologically active natural products. ${ }^{[1]}$ Such species are usually obtained by aldol- or Knoevenagel-type condensation reactions, and by Wittig and Horner-Wadsworth-Emmons olefination processes. ${ }^{[1,2]}$ However, in addition to their low atom economy, ${ }^{[3]}$ these classical methods generally require strongly basic media and therefore functional group compatibility and selectivity issues can be problematic. An alternative method of synthesis is the isomerization of propargylic alcohols by formal 1,3-shift of the hydroxyl moiety, which is known as the MeyerSchuster rearrangement (Scheme 1). ${ }^{[4]}$<smiles>[R]C#CC([R])([R])O</smiles>

Scheme 1. The Meyer-Schuster rearrangement of propargylic alcohols.

However, despite the accessibility of the starting materials, which can be easily generated by simple addition of metallated alkynes to aldehydes or ketones, and its complete atom economy, the Meyer-Schuster rearrangement has remained largely forgotten. This is due to the low selectivities often showed by the traditional protocols, which are based on the use of strong Brønsted acids under harsh reaction conditions. ${ }^{[5]}$ In particular, starting from substrates able to undergo a competitive Rupe-type rearrangement (Scheme 2), ${ }^{[6]}$ non-regioselective transformations are usually observed.

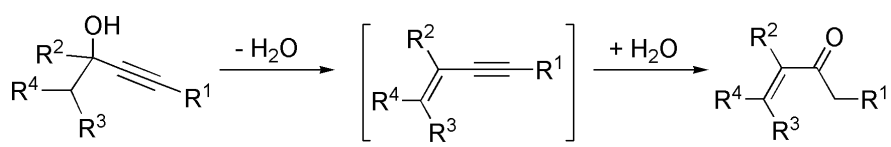

Scheme 2. The Rupe rearrangement of propargylic alcohols.

With the gradual emergence of new synthetic approaches based on the use of metal catalysts, more selective and efficient under milder reaction conditions, ${ }^{[7,8]}$ the Meyer-Schuster rearrengement has begun to play a more prominent role within the toolbox of synthetic organic chemists. In particular, remarkable results have been recently obtained by several groups in tandem processes involving the combination of this isomerization reaction with condensation, ${ }^{[9]}$ cyclocondensation, ${ }^{[10]}$ asymmetric hydrosilylation, ${ }^{[11]}$ Nazarov-type electrocyclization, ${ }^{[12]}$ Micheal-type addition, ${ }^{[13]}$ oxirane ring-opening, ${ }^{[14]}$ and allylic alkylation ${ }^{[15]}$ reactions, all of them allowing the rapid access to elaborated structures from readily available propargylic alcohols. ${ }^{[16]}$ Obviously, inclusion of this textbook transformation in future research programs is highly dependent on the availability of simple and effective catalytic systems, an area that remains open with many opportunities for new discoveries.

Metal oxides and oxo-complexes are among the most popular catalysts employed for the isomerization of alkynols since they show a remarkable selectivity towards the Meyer-Schuster vs Rupe reaction. ${ }^{[7]}$ This selectivity stems from the mechanism of action of these catalysts, which involves as the key step a [3,3]sigmatropic rearrangement of a metal-oxo-propargyloxo

[a] Prof. Dr. A. Antiñolo, Dr. F. Carrillo-Hermosilla, Prof. Dr. A. Otero Departamento de Química Inorgánica, Orgánica y Bioquímica Facultad de Ciencias Químicas - Campus de Ciudad Real Universidad de Castilla-La Mancha Campus Universitario, 13071 Ciudad Real (Spain)

Fax: (+34) 926-295-318 E-mail: Fernando.Carrillo@uclm.es

[b] Dr. V. Cadierno, Dr. J. García-Álvarez Departamento de Química Orgánica e Inorgánica IUQOEM (Unidad asociada al CSIC) Universidad de Oviedo Julián Claveria 8, 33006 Oviedo (Spain) Fax: (+34) 985-103-446

E-mail: garciajoaquin@uniovi.es

Supporting information for this article is available on the WWW under http://dx.doi.org/10.1002/cctc.200xxxxxx. 
intermediate $\mathbf{A}$, initially generated by transesterification of the metallic precursor with the propargylic alcohol (Scheme 3). ${ }^{[17,18]}$ Subsequent alkoxide exchange in the thus generated allenyloxo species $\mathbf{B}$ liberates the allenol $\mathbf{C}$, which readily tautomerizes into the desired $\alpha, \beta$-unsaturated carbonyl compound, and regenerates A. ${ }^{[19]}$

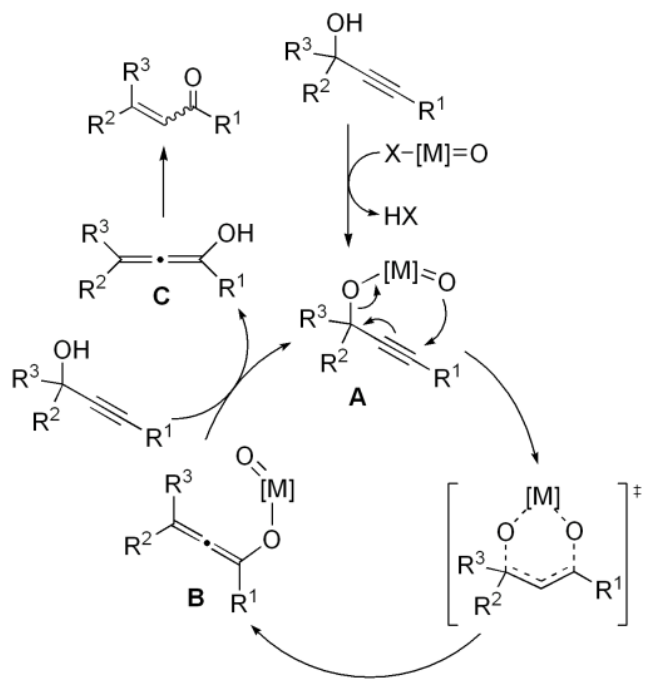

Scheme 3. General mechanism for the Meyer-Schuster rearrangement catalyzed by metal-oxo species.

In agreement with the well-known ability of oxo-vanadium(V) complexes to catalyze oxygen transfer reactions, ${ }^{[20]}$ several orthovanadate derivatives of general composition $\left[\mathrm{V}(\mathrm{O})(\mathrm{OR})_{3}\right](\mathrm{R}$ $=$ alkyl, aryl or silanyl group) have proven to act as promoters of Meyer-Schuster-type rearrangements. ${ }^{[21]}$ However, they usually operate under high temperature regimes $\left(140-160{ }^{\circ} \mathrm{C}\right)$ or in the presence of acidic co-catalysts, which limits seriously their synthetic applications. ${ }^{[22]}$

Quite recently, some of us have developed a simple, clean, selective and straightforward method of synthesis of chlorinated oxo-alkoxide complexes $\left[\mathrm{V}(\mathrm{O})(\mathrm{Cl})_{3-\mathrm{x}}(\mathrm{OR})_{\mathrm{x}}\right](\mathrm{x}=1$ or 2 ; $\mathrm{R}=$ alkyl group) by treatment of commercially available vanadyl chloride $\left[\mathrm{V}(\mathrm{O}) \mathrm{Cl}_{3}\right]$ with different excess of silicon ethers $\mathrm{ROSiMe}_{3}$ under mild conditions. ${ }^{[23]}$ The easy access to these complexes in multigram scale, along with the ability of their non-chlorinated $\left[\mathrm{V}(\mathrm{O})(\mathrm{OR})_{3}\right]$ counterparts to promote Meyer-Schuster rearrangements, prompted us to study the catalytic behavior of these species. We reasoned that the higher reactivity of the $\mathrm{V}-\mathrm{Cl}$ vs $\mathrm{V}$-OR bonds could facilitate the initial transesterification step (formation of intermediate $\mathbf{A}$ in Scheme 3), thus improving the effectiveness of this type of oxo-catalysts. As the reader will see, our guess was right and a new procedure for the selective MeyerSchuster isomerization of both terminal and internal alkynols could be developed using complex $\left[\mathrm{V}(\mathrm{O}) \mathrm{Cl}(\mathrm{OEt})_{2}\right]$ as catalyst. Thus, compared to the previously described $\left[\mathrm{V}(\mathrm{O})(\mathrm{OR})_{3}\right]$-based systems, complex $\left[\mathrm{V}(\mathrm{O}) \mathrm{Cl}(\mathrm{OEt})_{2}\right]$ was found to be operative under remarkably milder reaction conditions $\left(80^{\circ} \mathrm{O}\right)$ without the assistance of any additive.

\section{Results and Discussion}

To prove the catalytic potential of the oxo-vanadium( $\mathrm{V})$ compounds $\left[\mathrm{V}(\mathrm{O})(\mathrm{Cl})_{3-\mathrm{x}}(\mathrm{OR})_{\mathrm{x}}\right](\mathrm{x}=1$ or 2$)$, isomerization of commercially available 1,1-diphenyl-2-propyn-1-ol (3a) into 3,3- diphenylpropenal (4a) was firstly explored using complexes $\left[\mathrm{V}(\mathrm{O}) \mathrm{Cl}_{2}(\mathrm{OEt})\right](\mathbf{1})$ and $\left[\mathrm{V}(\mathrm{O}) \mathrm{Cl}(\mathrm{OEt})_{2}\right](\mathbf{2})$ as models (Scheme 4). Thus, we have found that, performing the catalytic reactions in toluene ( $1 \mathrm{M}$ solution of $3 \mathbf{3 a}$ ) at $80{ }^{\circ} \mathrm{C}$, both complexes were able to generate the desired enal $\mathbf{4 a}$ in high GC yields (91-96\%) after only 3-7 $\mathrm{h}$ of heating. Although a faster reaction was observed with the dichloride derivative $\left[\mathrm{V}(\mathrm{O}) \mathrm{Cl}_{2}(\mathrm{OEt})\right](\mathbf{1})$, the process was not completely selective since, in addition of $\mathbf{4 a}$, minor amounts ( $8 \%$ by GC) of a by-product were also formed. After chromatographic purification of the mixture, this by-product could be separated and identified spectroscopically as the known 2chloro-3,3-diphenylacrylaldehyde $\mathbf{5 a}$, resulting formally from the vinylic chlorination of $\mathbf{4 a}{ }^{[24]}$ Interestingly, such a chlorination process was not observed when the monochloride derivative $\left[\mathrm{V}(\mathrm{O}) \mathrm{Cl}(\mathrm{OEt})_{2}\right](2)$ was used as catalyst, pointing out the key role played by the number of chlorine atoms attached to vanadium on the chemoselectivity of this catalytic reaction.

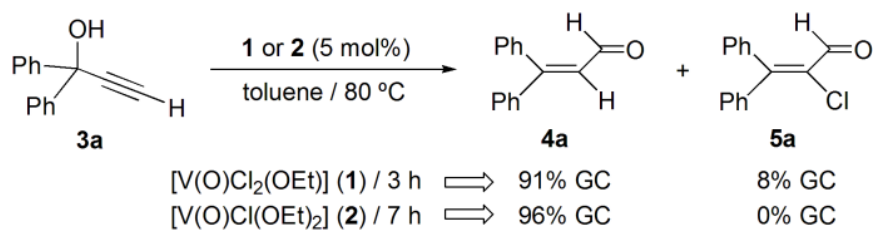

Scheme 4. The behaviour of 1,1-diphenyl-2-propyn-1-ol towards complexes $\left[\mathrm{V}(\mathrm{O}) \mathrm{Cl}_{2}(\mathrm{OEt})\right](\mathbf{1})$ and $\left[\mathrm{V}(\mathrm{O}) \mathrm{Cl}(\mathrm{OEt})_{2}\right](\mathbf{2})$.

The catalytic behaviour of the most selective catalyst $\left[\mathrm{V}(\mathrm{O}) \mathrm{Cl}(\mathrm{OEt})_{2}\right]$ (2) was then explored in different solvents (acetonitrile, acetone and THF) but, as shown in Table 1, the use of these polar media did not allow to improve the activity of 2 . Thus, although selective formation of enal $\mathbf{4 a}$ was in all cases observed, a longer reaction time $(24 \mathrm{~h})$ was required to attain similar or even poorer conversions (entries 2-4 vs 1 ).

Table 3. Isomerization of 1,1-diphenyl-2-propyn-1-ol (3a) into 3,3diphenylpropenal $(\mathbf{4 a})$ catalyzed by $\left[\mathrm{V}(\mathrm{O}) \mathrm{Cl}(\mathrm{OEt})_{2}\right](2)$ in different solvents. ${ }^{[\mathrm{a}]}$

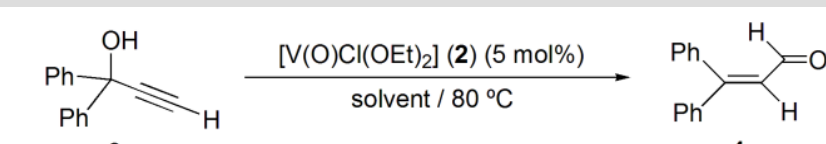

$3 a$

\begin{tabular}{|c|c|c|c|}
\hline Entry & Solvent & $\mathrm{t}[\mathrm{h}]$ & Yield $[\%]^{[b]}$ \\
\hline 1 & Toluene & 7 & 96 \\
\hline 2 & Acetonitrile & 24 & 94 \\
\hline 3 & Acetone & 24 & 42 \\
\hline 4 & Tetrahydrofuran & 24 & 96 \\
\hline $5^{[\mathrm{c}]}$ & Toluene & 0.5 & 97 \\
\hline
\end{tabular}

[a] Reactions were performed in a sealed tube under $\mathrm{N}_{2}$ atmosphere at $80 \stackrel{\circ}{\circ}$. 1 mmol of 1,1-diphenyl-2-propyn-1-ol (3a) was used (1.0 M solution). [Substrate]/[V] ratio $=100: 5$. [b] Yield of 3,3-diphenylpropenal (4a) determined by GC. [c] Reaction was performed under $\mathrm{N}_{2}$ atmosphere in a CEM Discover ${ }^{(}$ $\mathrm{S}$-Class microwave synthesizer at $80^{\circ} \mathrm{C}$ through moderation of the initial power $(300 \mathrm{~W})$

It is nowadays well recognized that the use of microwave (MW) irradiation represents a convenient alternative to the conventional thermal heating in organic synthesis since a more effective energy transfer to the system takes place, thus 
shortening considerably the reaction times and improving in many cases the product yields. ${ }^{[25]}$ Accordingly, we found that isomerization of $\mathbf{3 a}$ into $\mathbf{4 a}$ promoted by $\left[\mathrm{V}(\mathrm{O}) \mathrm{Cl}(\mathrm{OEt})_{2}\right]$ (2) proceeds almost quantitatively in only $30 \mathrm{~min}$ when $\mathrm{MW}$ irradiation $(300 \mathrm{~W})$ is used as the heating source $\left(80^{\circ} \mathrm{C}\right.$; entry 5 in Table 3). ${ }^{[26]}$ We must note that the effectiveness shown by 2 under these conditions surpass by far those previously reported for the classical oxo-vanadium $(\mathrm{V})$ catalysts $\left[\mathrm{V}(\mathrm{O})(\mathrm{OR})_{3}\right]$, ${ }^{[21]}$ and that of the highly reactive oxo-rhenium $(\mathrm{V})$ derivative $\left[\mathrm{Re}(\mathrm{O}) \mathrm{Cl}_{3}\left(\mathrm{OPPh}_{3}\right)\left(\mathrm{SMe}_{2}\right)\right]$ recently described by Vidari and coworkers. ${ }^{[16 a]}$ In fact, isomerization of $\mathbf{3 a}$ using the latter $(5 \mathrm{~mol} \%$ loading) leads to 3,3-diphenylpropenal (4a) in 96\% only after $20 \mathrm{~h}$ of heating at $80{ }^{\circ} \mathrm{C} .^{[16 \mathrm{a}]}$

Under these optimized reaction conditions, complex $\left[\mathrm{V}(\mathrm{O})(\mathrm{Cl})(\mathrm{OEt})_{2}\right](2)$ was found to be an efficient catalyst for the selective isomerization of a large number of other propargylic alcohols, thus proving the wide scope and synthetic utility of this catalytic transformation. Thus, as observed for 1,1-diphenyl-2propyn-1-ol (entry 1 in Table 2), other tertiary alkynols $\mathbf{3 b - h}$ underwent fast $(0.25-2.5 \mathrm{~h})$ and selective isomerization into the corresponding enals $\mathbf{4} \mathbf{b}-\mathbf{h}$, which could be isolated after appropriate chromatographic workup in excellent yields (91-95\%; entries 2-8 in Table 2). Influence of the electronic properties of the aryl rings on the reaction rates was observed. Thus, alkynols with electron-withdrawing groups showed less reactivity (entries 4-5) as compared to the substrates with electron-donating substituents (entries 6-7).

Table 2. Isomerization of tertiary propargylic alcohols $3 a-h$ into enals $4 a-h$ catalyzed by $\left[\mathrm{V}(\mathrm{O}) \mathrm{Cl}(\mathrm{OEt})_{2}\right](2){ }^{\left[{ }^{[a]}\right.}$

\begin{tabular}{|c|c|c|c|c|}
\hline \multicolumn{2}{|r|}{$3 a-h$} & $\frac{\left[\mathrm{V}(\mathrm{O}) \mathrm{Cl}(\mathrm{OEt})_{2}\right](2)(5}{\text { toluene } / 80^{\circ} \mathrm{C} / \mathrm{MW}(}$ & & $4 a-h$ \\
\hline Entry & Sub & & $\mathrm{t}[\mathrm{h}]$ & Yield of $4[\%]^{[b]}$ \\
\hline 1 & $\mathrm{R}^{1}=$ & h (3a) & 0.5 & 4a; $97(93)$ \\
\hline 2 & $R^{1} R$ & $-\mathrm{C}_{6} \mathrm{H}_{4}-\mathrm{C}_{6} \mathrm{H}_{4}(\mathbf{3 b})$ & 1 & $4 b ; 98$ (91) \\
\hline 3 & $R^{1} R$ & $\mathrm{C}_{6} \mathrm{H}_{4}-\mathrm{CH}=\mathrm{CH}-\mathrm{C}_{6} \mathrm{H}_{4}(3 \mathrm{c})$ & 0.5 & 4c; $99(95)$ \\
\hline 4 & $\mathrm{R}^{1}=$ & $\mathrm{C}_{6} \mathrm{H}_{4} \mathrm{~F}(\mathbf{3 d})$ & 2.5 & 4d; 98 (93) \\
\hline 5 & $\mathrm{R}^{1}=$ & $\mathrm{C}_{6} \mathrm{H}_{4} \mathrm{Cl}(\mathbf{3 e})$ & 1 & 4e; $96(93)$ \\
\hline 6 & $\mathrm{R}^{1}=$ & $\mathrm{C}_{6} \mathrm{H}_{4} \mathrm{OMe}(\mathbf{3 f})$ & 0.25 & 4f; 97 (92) \\
\hline 7 & $\mathrm{R}^{1}=$ & $\mathrm{C}_{6} \mathrm{H}_{4} \mathrm{Me}(\mathbf{3 g})$ & 0.33 & $\mathbf{4 g} ; 98(94)$ \\
\hline 8 & $\mathrm{R}^{1}=$ & $=\mathrm{Ph}(3 \mathrm{~h})$ & 1 & $4 h ; 98(93)^{[c]}$ \\
\hline
\end{tabular}

[a] Reactions were performed under $\mathrm{N}_{2}$ atmosphere in a CEM Discover ${ }^{\circledR} \mathrm{S}$ Class microwave synthesizer at $80{ }^{\circ} \mathrm{C}$ through moderation of the initial power $(300 \mathrm{~W}) .1 \mathrm{mmol}$ of the corresponding alkynol was used $(1.0 \mathrm{M}$ solution in toluene). [Substrate]/[V] ratio $=100: 5$. [b] Determined by GC. Isolated yields after chromatographic workup are given in brackets. [c] A mixture of $E$ and $Z$ isomers in ca. 3:2 ratio is formed.

The behaviour of complex 2 towards 2-phenyl-3-butyn-2-ol (3h, entry 8 ), a propargylic alcohol bearing a $\mathrm{C}-\mathrm{H}$ bond in $\beta$ position respect to the alcohol group in which the isomerization process can proceed through the competitive Rupe-type rearrangement, was also explored. Gratifyingly, exclusive formation of the $\alpha, \beta$-unsaturated enal $\mathbf{4 h}$, as a mixture of the corresponding $E$ and $Z$ stereoisomers in ca. 3:2 ratio, was observed. ${ }^{[27]}$ In an attemp to improve the stereoselectivity of this reaction we decided to increase the steric congestion on the vanadium center by replacing one of the ethoxy groups (OEt) by the bulkier adamantoxy one (OAd). This was easily achieved just by adding a stoichiometric amount of 1-adamantanol to a dichloromethane solution of complex $\left[\mathrm{V}(\mathrm{O}) \mathrm{Cl}(\mathrm{OEt})_{2}\right]$ (2). The reaction yields the mixed-alkoxy vanadate complex $[\mathrm{V}(\mathrm{O}) \mathrm{Cl}(\mathrm{OEt})(\mathrm{OAd})](6)$ in good yield $(97 \%)$ as an orange oil (synthetic details and characterization data are given in the Experimental Section). Unfortunately, the use of $\mathbf{6}$ as catalyst (5 mol\%) led to the same mixture of $E / Z$ isomers in $98 \%$ GC-yield after $1.5 \mathrm{~h}$ of MW irradiation. This fact clearly indicates that the stereochemistry of the $\mathrm{C}=\mathrm{C}$ bond is fixed out of the coordination sphere of the metal.

Secondary terminal alkynols (Table 3 ) can also be efficient and selective isomerized into the corresponding enals using $\left[\mathrm{V}(\mathrm{O})(\mathrm{Cl})(\mathrm{OEt})_{2}\right](\mathbf{2})$. Again, reactions proceeded to completion in the absence of any co-catalyst. However, in these cases, longer reaction times when compared with the aforementioned tertiary propargylic alcohols were required (4-8 vs 0.25-2.5 h). Interestingly, in contrast to $\mathbf{4 h}$, the resulting enals $\mathbf{4 i - n}$ were now exclusively obtained as the thermodynamically more stable $E$ isomers, regardless of the electronic properties of the aromatic substituents present in the molecule. ${ }^{[28]}$

Table 3. Isomerization of secondary propargylic alcohols $3 \mathbf{i}-\mathbf{n}$ into enals $4 \mathbf{i}-\mathbf{n}$ catalyzed by $\left[\mathrm{V}(\mathrm{O}) \mathrm{Cl}(\mathrm{OEt})_{2}\right](2){ }^{[\mathrm{a}]}$

\begin{tabular}{|c|c|c|c|c|}
\hline \multicolumn{2}{|r|}{$\mathrm{PH}_{3 \mathrm{i}-\mathrm{n}}^{\mathrm{OH}}$} & $\frac{[\mathrm{V}(\mathrm{O})}{\text { toluen }}$ & $\frac{2)(5 r}{M W(}$ & $4 i-n$ \\
\hline Entry & Subs & & $t[h]$ & Yield of $\mathbf{4}[\%]^{[b]}$ \\
\hline 1 & $\mathrm{R}=\mathrm{F}$ & & 5 & $4 \mathbf{i} ; 97(92)$ \\
\hline 2 & $R=2$ & yl (3j) & 8 & 4j; 97 (91) \\
\hline 3 & $R=2$ & $\operatorname{Me}(\mathbf{3 k})$ & 4 & 4k; 95 (87) \\
\hline 4 & $\mathrm{R}=4$ & (3I) & 7 & 4I; 95 (89) \\
\hline 5 & $\mathrm{R}=4$ & he $(3 m)$ & 6 & $4 \mathrm{~m} ; 97$ (91) \\
\hline 6 & $R=2$ & $(3 n)$ & 4 & 4n; 95 (92) \\
\hline \multicolumn{5}{|c|}{$\begin{array}{l}\text { [a] Reactions were performed under } \mathrm{N}_{2} \text { atmosphere in a CEM Discover }{ }^{\circledR} \mathrm{S} \text { - } \\
\text { Class microwave synthesizer at } 80 \stackrel{\circ}{ } \mathrm{C} \text { through moderation of the initial power } \\
(300 \mathrm{~W}) .1 \mathrm{mmol} \text { of the corresponding alkynol was used }(1.0 \mathrm{M} \text { solution in } \\
\text { toluene). [Substrate]/[V] ratio }=100: 5 \text {. [b] Determined by GC. Isolated yields } \\
\text { after chromatographic workup are given in brackets. }\end{array}$} \\
\hline
\end{tabular}

As shown in Table 4, the effectiveness of complex $\left[\mathrm{V}(\mathrm{O}) \mathrm{Cl}(\mathrm{OEt})_{2}\right](2)$ is not restricted to propargylic alcohols bearing a terminal $\mathrm{C} \equiv \mathrm{C}$ bond, the internal ones 7a-f being also efficiently transformed into the corresponding enones 8a-f under identical reaction conditions (91-95\% isolated yields after $0.5-6.5 \mathrm{~h}$ of $\mathrm{MW}$ irradiation). Both tertiary (7a-b; entries 1-2) and secondary (7c-f; entries 3-5) alcohols were tolerated, the latter leading to enones $8 \mathbf{c}$-f with complete $E$-stereoselectivity. The clean isomerization of the $\mathrm{CF}_{3}$-containing propargylic alcohol $\mathbf{7 b}$ into enone $\mathbf{8 b}$ (entry 2) merits to be highlighted since $\alpha, \beta$-unsaturated trifluoromethylketones $R^{1} R^{2} C=C\left(R^{3}\right) C(=O) C F_{3}$ are important building blocks in organic synthesis. Indeed, the enhanced reactivity of these 
derivatives, as compared to their nonfluorinated counterparts, has been widely exploited in a large number of processes including Diels-Alder cycloadditions and Michael-type additions. ${ }^{[29]}$ As far as we are aware, transformation of $\mathbf{7 b}$ into $\mathbf{8 b}$ represents the first example of a Meyer-Schuster rearrangement of propargylic alcohols with a trifluoromethyl group at the distal position of the $\mathrm{C} \equiv \mathrm{C}$ triple bond, ${ }^{[30]}$ thus opening a new route of access to these relevant enones. ${ }^{[31]}$

\begin{tabular}{|c|c|c|c|c|}
\hline \multicolumn{2}{|c|}{$7 a-f$} & \multicolumn{2}{|c|}{$\frac{\left[\mathrm{V}(\mathrm{O}) \mathrm{Cl}(\mathrm{OEt})_{2}\right](\mathbf{2})(5 \mathrm{~mol} \%)}{\text { toluene } / 80^{\circ} \mathrm{C} / \mathrm{MW}(300 \mathrm{~W})}$} & \multirow{2}{*}{ Yield of $8[\%]^{[b]}$} \\
\hline Entry & Substrate 7 & & $\mathrm{t}[\mathrm{h}]$ & \\
\hline 1 & $R^{1}=R^{2}=R^{3}$ & ${ }^{3}=\mathrm{Ph}(\mathbf{7 a})$ & 0.5 & $8 \mathbf{8} ; 99(95)$ \\
\hline 2 & $\mathrm{R}^{1}=\mathrm{CF}_{3} ; \mathrm{R}^{2}$ & ${ }^{2}=\mathrm{R}^{3}=\mathrm{Ph}(\mathbf{7 b})$ & 1 & 8b; 96 (92) \\
\hline 3 & $\mathrm{R}^{1}=\mathrm{Me} ; \mathrm{R}^{2}$ & $=\mathrm{Ph} ; \mathrm{R}^{3}=\mathrm{H}(\mathbf{7 c})$ & 6 & $8 c ; 96(91)^{[c]}$ \\
\hline 4 & $\mathrm{R}^{1}=\mathrm{Me} ; \mathrm{R}^{2}$ & $=4-\mathrm{C}_{6} \mathrm{H}_{4} \mathrm{OMe} ; \mathrm{R}^{3}=\mathrm{H}(\mathbf{7 d})$ & 3.5 & $8 d ; 97(94)^{[c]}$ \\
\hline 5 & $\mathrm{R}^{1}=\mathrm{Me} ; \mathrm{R}^{2}$ & $=4-\mathrm{C}_{6} \mathrm{H}_{4} \mathrm{SMe} ; \mathrm{R}^{3}=\mathrm{H}(7 \mathrm{e})$ & 6.5 & $8 \mathbf{8 e} ; 96(93)^{[c]}$ \\
\hline 6 & $\mathrm{R}^{1}=\mathrm{Ph} ; \mathrm{R}^{2}$ & $=\mathrm{Ph} ; \mathrm{R}^{3}=\mathrm{H}(\mathbf{7 f})$ & 0.5 & $8 f ; 98(94)^{[c]}$ \\
\hline
\end{tabular}

[a] Reactions were performed under $\mathrm{N}_{2}$ atmosphere in a CEM Discover ${ }^{\circledR} \mathrm{S}$ Class microwave synthesizer at $80 \stackrel{\circ}{ } \mathrm{C}$ through moderation of the initial power $(300 \mathrm{~W}) .1 \mathrm{mmol}$ of the corresponding alkynol was used $(1.0 \mathrm{M}$ solution in toluene). [Substrate]/[V] ratio $=100: 5$. [b] Determined by GC. Isolated yields after chromatographic workup are given in brackets. [c] E-isomers were exclusively formed.

Finally, we must note that the limitations of this new methodology are: $i$ ) the scope of this transformation is limited to benzylic alcohols, and ii) the use of primary propargylic alcohols $\mathrm{RC} \equiv \mathrm{CCH}_{2} \mathrm{OH}$, which under the standard reaction conditions give rise to intractable polymeric materials. ${ }^{[32]}$

\section{Conclusion}

In summary, a novel procedure for the Meyer-Schuster rearrangement of propargylic alcohols has been developed using the oxo-vanadium $(\mathrm{V})$ complex $\left[\mathrm{V}(\mathrm{O}) \mathrm{Cl}(\mathrm{OEt})_{2}\right]$, a readily accessible species which can be generated at the multigram scale from commercially available vanadyl chloride $\left[\mathrm{V}(\mathrm{O}) \mathrm{Cl}_{3}\right]$ and ethoxytrimethylsilane $\mathrm{EtOSiMe}_{3}$ in a single step. Thus, under MW irradiation, this compound was able to isomerize both terminal and internal propargylic alcohols into the corresponding $\alpha, \beta$ unsaturated carbonyl compounds, which can be obtained: $i$ ) under mild conditions $\left(80^{\circ} \mathrm{C}\right)$ ) as compared to the previously reported examples using orthovanadate derivatives $\left[\mathrm{V}(\mathrm{O})(\mathrm{OR})_{3}\right]$, ii) in excellent yields, iii) in most cases, in a time-scale reaction of minutes, and $i \mathrm{v}$ ) under neutral conditions assisted by microwave irradiation. This catalyst has also proven to promote chemoselective and regioselective transformations, leading in all cases to the most stable $E$-isomers when secondary propargylic alcohols are used as substrates. To the best of our knowledge, complex $\left[\mathrm{V}(\mathrm{O}) \mathrm{Cl}(\mathrm{OEt})_{2}\right]$, along with the oxo-rhenium $(\mathrm{V})$ derivative $\left[\mathrm{Re}(\mathrm{O}) \mathrm{Cl}_{3}\left(\mathrm{OPPh}_{3}\right)\left(\mathrm{SMe}_{2}\right)\right]$ recently described by Vidari and coworkers ${ }^{[16 a]}$ are the most efficient oxo-catalysts reported to date in the literature for this relevant transformation. We are confident that this simple methodology can be of interest to a wide range of synthetic organic chemists, which could make use in future research programs.

\section{Experimental Section}

General methods: Synthetic procedures were performed under an atmosphere of dry nitrogen. Solvents were dried by standard methods and distilled under nitrogen before use. All reagents were obtained from commercial suppliers and used without further purification, with the exception of complexes $\left[\mathrm{V}(\mathrm{O}) \mathrm{Cl}_{2}(\mathrm{OEt})\right](\mathbf{1})$ and $\left[\mathrm{V}(\mathrm{O}) \mathrm{Cl}(\mathrm{OEt})_{2}\right]$ (2), ${ }^{[23]}$ the terminal propargylic alcohols $3 \mathbf{b}-\mathbf{g}$ and $3 \mathbf{j}-\mathbf{n},{ }^{[33]}$ and the internal ones $\mathbf{7 b}-\mathbf{e},{ }^{[28 a, 30,34]}$ which were prepared by following the methods reported in the literature. Flash chromatography was performed using Merck silica gel 60 (230-400 mesh).

General procedure for the catalytic Meyer-Schuster rearrangements using $\left[\mathrm{V}(\mathrm{O}) \mathrm{Cl}(\mathrm{OEt})_{2}\right] \quad(2)$ : Under nitrogen atmosphere, a pressure-resistant septum-sealed glass vial was charged with the corresponding propargylic alcohol $(1 \mathrm{mmol})$, $\left[\mathrm{V}(\mathrm{O}) \mathrm{Cl}(\mathrm{OEt})_{2}\right](0.010 \mathrm{~g}, 5 \mathrm{~mol} \%)$, a magnetic stirring bar and toluene $(1 \mathrm{~mL})$. The vial was then placed inside the cavity of a CEM Discover ${ }^{\circledR}$ S-Class microwave synthesizer and power was held at $300 \mathrm{~W}$ until the desired temperature $\left(80^{\circ} \mathrm{C}\right)$ was reached. Microwave power was automatically regulated for the remainder of the experiment to maintain the temperature (monitored by a built-in infrared sensor). The course of the reaction was monitored by regular sampling and analysis by GC. After completion of the reaction (see Tables 2-4), the vial was cooled and the crude of the reaction was purified by flash chromatography over silica gel using EtOAc/hexane (1:10) as eluent. The identity of the resulting $\alpha, \beta$-unsaturated carbonyl compounds was assessed by comparison of their ${ }^{1} \mathrm{H}$ and ${ }^{13} \mathrm{C}\left\{{ }^{1} \mathrm{H}\right\}$ NMR spectroscopic data (copies of the spectra are included in the Supporting Information file) with those reported in the literature and by their fragmentation in GC/MS.

Synthesis of complex $[\mathrm{V}(\mathrm{O}) \mathrm{Cl}(\mathrm{OEt})(\mathrm{OAd})]$ (6): Under nitrogen atmosphere, a solution of 1-adamantanol $(0.79 \mathrm{~g}, 5.20 \mathrm{mmol})$ in 10 $\mathrm{mL}$ of dichloromethane was slowly added to a solution of $\left[\mathrm{V}(\mathrm{O}) \mathrm{Cl}(\mathrm{OEt})_{2}\right](2)(1.00 \mathrm{~g}, 5.20 \mathrm{mmol})$ in $10 \mathrm{~mL}$ of dichloromethane. The reaction mixture was stirred for 2 hours at room temperature to obtain a light orange solution. The solvent was then removed under vacuum to give compound 6 as an orange oil. Yield: $1.50 \mathrm{~g}(97 \%) ;{ }^{1} \mathrm{H}$ $\operatorname{NMR}\left(500 \mathrm{MHz}, \mathrm{CDCl}_{3}, 25^{\circ} \mathrm{C}\right): \delta=1.57\left(\mathrm{t}, J=7 \mathrm{~Hz}, 3 \mathrm{H}, \mathrm{OCH}_{2} \mathrm{CH}_{3}\right)$, $1.70 \quad\left(\mathrm{~m}, \quad 6 \mathrm{H}, \quad \mathrm{OC}\left(\mathrm{CH}_{2}\right)_{3}(\mathrm{CH})_{3}\left(\mathrm{CH}_{2}\right)_{3}\right), \quad 2.08 \quad(\mathrm{~m}, \quad 6 \mathrm{H}$, $\left.\mathrm{OC}\left(\mathrm{CH}_{2}\right)_{3}(\mathrm{CH})_{3}\left(\mathrm{CH}_{2}\right)_{3}\right), 2.29$ (br s, 3H, OC $\left(\mathrm{CH}_{2}\right)_{3}\left(\mathrm{CH}_{3}\left(\mathrm{CH}_{2}\right)_{3}\right), 5.33$ (q, $\left.J=7 \mathrm{~Hz}, 2 \mathrm{H}, \mathrm{OCH}_{2} \mathrm{CH}_{3}\right) \mathrm{ppm} ;{ }^{13} \mathrm{C}\left\{{ }^{1} \mathrm{H}\right\} \mathrm{NMR}\left(125 \mathrm{MHz}, \mathrm{CDCl}_{3}, 25 \stackrel{\circ}{\circ} \mathrm{C}\right)$ : $\delta=19.12\left(\mathrm{OCH}_{2} \mathrm{CH}_{3}\right), \quad 31.55\left(\mathrm{OC}\left(\mathrm{CH}_{2}\right)_{3}(\mathrm{CH})_{3}\left(\mathrm{CH}_{2}\right)_{3}\right), \quad 35.98$ $\left(\mathrm{OC}\left(\mathrm{CH}_{2}\right)_{3}(\mathrm{CH})_{3}\left(\mathrm{CH}_{2}\right)_{3}\right), \quad 45.04 \quad\left(\mathrm{OC}\left(\mathrm{CH}_{2}\right)_{3}\left(\mathrm{CH}_{3}\left(\mathrm{CH}_{2}\right)_{3}\right), \quad 82.86\right.$ $\left(\mathrm{OCH}_{2} \mathrm{CH}_{3}\right), 91.67\left(\mathrm{OC}\left(\mathrm{CH}_{2}\right)_{3}(\mathrm{CH})_{3}\left(\mathrm{CH}_{2}\right)_{3}\right)$; Elemental analysis calcd (\%) for $\mathrm{C}_{12} \mathrm{H}_{20} \mathrm{ClO}_{3} \mathrm{~V}(298.7 \mathrm{~g} / \mathrm{mol}): \mathrm{C} 48.26, \mathrm{H} 6.75$; found: $\mathrm{C} 48.50, \mathrm{H}$ 2.85 .

\section{Acknowledgements}

We gratefully acknowledge financial support from the Ministerio de Ciencia e Innovación (MICINN) of Spain (CSD2007-00006, CTQ2008-00506/BQU, CTQ2010-14796/BQU, and CTQ200909214/BQU) and the Junta de Comunidades de Castilla-La Mancha (PCI08-0032). J.G.-A. thanks also MICINN and the European Social Fund for the award of a "Juan de la Cierva" contract.

Keywords: Vanadium • Meyer-Schuster rearrangement • Propargylic alcohols • Enals $\cdot$ MW-assisted synthesis 
[1] See, for example: a) M. E. Jung, in Comprehensive Organic Synthesis, Vol. 4 (Eds: B. M. Trost, I. Fleming, M. F. Semmelhack), Pergamon Press, Oxford, 1991, pp. 1-67; b) V. J. Lee, in Comprehensive Organic Synthesis, Vol. 4 (Eds: B. M. Trost, I. Fleming, M. F. Semmelhack), Pergamon Press, Oxford, 1991, pp. 69-137; c) V. J. Lee, in Comprehensive Organic Synthesis, Vol. 4 (Eds: B. M. Trost, I. Fleming, M. F. Semmelhack), Pergamon Press, Oxford, 1991, pp. 139-168; d) J. A Kozlowski, in Comprehensive Organic Synthesis, Vol. 4 (Eds: B. M. Trost I. Fleming, M. F. Semmelhack), Pergamon Press, Oxford, 1991, pp. 169198; e) K. Bauer, D. Garbe, H. Surburg, in Common Fragrance and Flavour Materials, Wiley-VCH, Weinheim, 2001; f) S. P. Marsden, in Science of Synthesis, Vol. 26 (Ed: J. Cossy), Thieme Verlag, Stuttgart, 2004, pp. 1045-1121; g) I. Escher, F. Glorius, in Science of Synthesis, Vol. 25 (Ed: Brückner), Thieme Verlag, Stuttgart, 2006, pp. 733-777.

[2] J. Clayden, N. Greeves, S. Warren, P. Wothers, in Organic Chemistry, Oxford University Press, Oxford, 2001.

[3] For review articles highlighting the concept of atom economy, see: a) B. M. Trost, Science 1991, 254, 1471-1477; b) B. M. Trost, Angew. Chem. 1995, 107, 285-307; Angew. Chem. Int. Ed.. 1995, 34, 259-281; c) R. A Sheldon, Pure Appl. Chem. 2000, 72, 1233-1246; d) B. M. Trost, Acc. Chem. Res. 2002, 35, 695-705; e) B. M. Trost, M. U. Frederiksen, M. T. Rudd, Angew. Chem. 2005, 117, 6788-6825; Angew. Chem. Int. Ed. 2005, 44, 6630-6666; f) R. A. Sheldon, Green Chem. 2007, 9, 1273-1283.

[4] K. H. Meyer, K. Schuster, Ber. Dtsch. Chem. Ges. 1922, 55, 819-823.

[5] For early reviews, see: a) S. A. Vartanyan, S. O. Babanyan, Russ. Chem. Rev. 1967, 36, 670-686; b) S. Swaminathan, K. V. Narayanan, Chem. Rev. 1971, 71, 429-438.

[6] H. Rupe, E. Kambli, Helv. Chim. Acta 1926, 9, 672.

[7] For reviews on metal-catalyzed Meyer-Schuster rearrangements, see: a) D. A. Engel, G. B. Dudley, Org. Biomol. Chem. 2009, 7, 4149-4158; b) V. Cadierno, P. Crochet, S. E. García-Garrido, J. Gimeno, Dalton Trans. 2010, 39, 4015-4031.

[8] A protocol for the selective Meyer-Schuster rearrangement of propargylic alcohols using boronic acids as catalysts under mild conditions has been recently disclosed: H. Zhang, M. Lejkowski, D. G. Hall, Chem. Sci. 2011, 2, 1305-1310.

[9] a) V. Cadierno, J. Díez, S. E. García-Garrido, J. Gimeno, N. Nebra, Adv. Synth. Catal. 2006, 348, 2125-2132; b) J. Borge, V. Cadierno, J. Díez, S. E. García-Garrido, J. Gimeno, Dyes Pigm. 2010, 87, 209-217.

[10] a) B. Alcaide, P. Almendros, M. T. Quirós, Adv. Synth. Catal. 2011, 353, 585-594; b) R. Sarma, D. Prajapati, Synlett 2008, 3001-3005; c) K. C. Lekhok, D. Prajapati, R. C. Boruah, Synlett 2008, 655-658.

[11] K. A. Nolin, R. W. Ahn, Y. Kobayashi, J. J. Kennedy-Smith, F. D. Toste, Chem. Eur. J. 2010, 16, 9555-9562.

[12] a) C. J. Rieder, K. J. Winberg, F. G. West, J. Am. Chem. Soc. 2009, 131 7504-7505; b) C. J. Rieder, K. J. Winberg, F. G. West, J. Org. Chem. 2011, 76, 50-56.

[13] a) S. Bhuvaneswari, M. Jeganmohan, C.-H. Cheng, Chem. Asian J. 2010 5, 141-146; b) C. Schwehm, M. Wohland, M. E. Maier, Synlett 2010 1789-1792; c) M. Wohland, M. E. Maier, Synlett 2011, 1523-1526.

[14] L.-Z. Dai, M. Shi, Chem. Eur. J. 2008, 14, 7011-7018.

[15] B. M. Trost, X. Luan, J. Am. Chem. Soc. 2011, 133, 1706-1709.

[16] Application of metal-catalyzed Meyer-Schuster rearrangements to the synthesis of $(S)$ - $\alpha$-ionone and prostaglandins has also been recently described: a) M. Stefanoni, M. Luparia, A. Porta, G. Zanoni, G. G. Vidari, Chem. Eur. J. 2009, 15, 3940-3944; b) R. S. Ramón, S. Gaillard, A. M. Z. Slawin, A. Porta, A. D’Alfonso, G. Zanoni, S. P. Nolan, Organometallics 2010, 29, 3665-3668; c) G. Zanoni, A. D’Alfonso, A. Porta, L. Feliciani, S. P. Nolan, G. Vidari, Tetrahedron 2010, 66, 7472-7478.

[17] The mechanism of the isomerization of 2-methyl-3-butyn-2-ol into 3methyl-2-butenal, catalyzed by an oxo titanium complex, has been previously investigated by synthesizing several compounds that mode the postulated metal-oxo-propargyloxo intermediate. C. Y. Lorber, M.-T. Youinou, J. Kress, J. A. Osborn, Polyhedron 2000, 19, 1693-1698.

[18] The basis of this reaction is a [3,3]-sigmatropic transposition of the metal-oxo intermediate. Similar reactions are also known for allylic alcohols using molybdenum, vanadium or rhenium catalyst. a) T. Hosogai, Y. Fujita, Y. Ninagawa, T. Nishida Chem. Lett. 1982, 357-360 b) S. Matsubara, T. Okazoe, K. Oshima, K. Takai, H. Nozaki Bull. Chem. Soc. Jpn. 1985, 58, 844-849; c) J. Belgacem, J. Kress, J. A. Osborn J. Am. Chem. Soc. 1992, 114, 1501-1502; d) J. Belgacem, J. Kress, J. A. Osborn J. Mol. Catal. 1994, 86, 267-285; e) S. Bellemin-Laponnaz, H.
Gisie, J. P. Le Ny, J. A. Osborn, Angew. Chem. Int. Ed. 1997, 36, 976978; f) S. Bellemin-Laponnaz, J. P. Le Ny, J. A. Osborn, Tetrahedron Lett. 2000, 41, 1549-1552; g) S. Akai, K. Tanimoto, Y. Kanao, M. Egi, T. Yamamoto, Y. Kita Angew. Chem. Int. Ed. 2006, 45, 2592-2595; i) C. Morrill, G. L. Beutner, R. H. Grubbs J. Org. Chem. 2006, 71, 7813-7825; j) E. C. Hansen, D. J. Lee J. Am. Chem. Soc. 2006, 128, 8142-8143; k) A T. Hermann, T. Saito, C. E. Stivala, J. Tom, A. Zakarian J. Am. Chem. Soc. 2010, 132, 5962-5963.

[19] a) Variants involving the direct addition of the propargylic $\mathrm{OH}$ group across the $\mathrm{M}=\mathrm{O}$ bond have also been proposed, a hydroxo-propargyloxo species $\left[M(O H)\left(O C R^{2} R^{3} C \equiv C R^{1}\right)\right]$ being in this case involved in the [3,3]sigmatropic rearrangement: see reference $16 \mathrm{a} ; \mathrm{b}$ ) Introduction of a Lewis acid co-catalyst able to coordinate to the $\mathrm{C} \equiv \mathrm{C}$ bond of the propargylic alcohol is also known to favour the key [3,3]-sigmatropic rearrangement step: M. Egi, Y. Yamaguchi, N. Fujiwara, S. Akai, Org. Lett. 2008, 10, 1867-1870.

[20] For a recent review, see: G. Licini, V. Conte, A. Coletti, M. Mba, C. Zonta, Coord. Chem. Rev. 2011, in press (doi:10.1016/j.ccr.2011.05.004).

[21] a) P. Chabardes, Y. Querou, Fr. Pat. FR1554805, 1969; b) P. Chabardes, Y. Querou, U.S. Pat. US3920751, 1975; c) M. B. Ernan, I. S. Aulchenko, L. A. Kheifits, V. G. Dulova, J. N. Novikov, M. E. Volpin, Tetrahedron Lett 1976, 34, 2981-2984; d) G. L. Olson, K. D. Morgan, G. Saucy, Synthesis 1976, 25-26; e) G. L. Olson, H.-C. Cheung, K. D. Morgan, R. Borer, G. Saucy, Helv. Chim. Acta 1976, 59, 567-585; f) H. Pauling, D. A. Andrews, N. C. Hindley, Helv. Chim. Acta 1976, 59, 1233-1243; g) P. Chabardes, E. Kuntz, J. Varagnat, Tetrahedron 1977, 33, 1775-1783; h) P. Chabardes, E. Kuntz, Ger. Pat. DE2657335, 1977; i) K. Bruns, U. Weber, in Flavors and Fragrances: A World Perspective, (Eds: B. M. Lawrence, B. D. Mookherjee, B. J. Willis), Elsevier Science Publishers, Amsterdam, 1988; j) B. M. Choudary, A. D. Prasad, V. L. K. Valli, Tetrahedron Lett. 1990, 31, 7521-7522; k) M. B. Erman, S. E. Gulyi, I. S. Aulchenko, Mendeleev Commun. 1994, 89; I) B. M. Trost, C. K. Chung, J. Am. Chem. Soc. 2006, 128, 10358-10359; m) see also reference 15.

[22] Meyer-Schuster isomerization of ethoxyalkynyl carbinols catalyzed by the vanadium(IV) derivative $\left[\mathrm{V}(\mathrm{O})(\mathrm{acac})_{2}\right]$ has also been described: See, reference 12.

[23] J. Romero-Fernández, F. Carrillo-Hermosilla, A. Antiñolo, C. AlonsoMoreno, A. M. Rodríguez, I. López-Solera, A Otero, Dalton Trans. 2010, 39, 6419-6425.

[24] N. Kamigata, T. Satoh, M. Yoshida, Bull. Chem. Soc. Jpn. 1988, 61, 449454.

[25] See, for example: a) Microwaves in Organic Synthesis, (Ed: A. Loupy), Wiley-VCH, Weinheim, 2006; b) C. O. Kappe, D. Dallinger, S. S. Murphee, in Practical Microwave Synthesis for Organic Chemists, WileyVCH, Weinheim, 2009; c) Microwave Heating as a Tool for Sustainable Chemistry, (Ed: N. E. Leadbeater), CRC Press, Boca Raton, 2011.

[26] The use of lower temperatures and/or catalyst loadings slowed down the reaction considerably; as an example, by using $1 \mathrm{~mol} \%$ of complex 2 under microwave irradiation ( $300 \mathrm{~W})$ at $80{ }^{\circ} \mathrm{C}$, 3,3-diphenylpropenal is formed in only $80 \%$ GC yield after $1 \mathrm{~h}$

[27] This total Meyer-Schuster vs Rupe selectivity was also previously observed for the related vanadium(V)-catalyst $\left[\mathrm{V}(\mathrm{O})\left(\mathrm{OSiPh}_{3}\right)_{3}\right]$. See reference $19 \mathrm{~g}$.

[28] Such an E-selectivity with secondary alkynols has been rarely observed using oxo-complexes as catalysts (ref. 16a). However, several examples of stereoselective non-oxo catalytic systems are known. See, for example, references $16 \mathrm{~b}-\mathrm{c}$ and: a) V. Cadierno, J. Francos, J. Gimeno, Tetrahedron Lett. 2009, 50, 4773-4776; b) V. Cadierno, S. E. GarcíaGarrido, J. Gimeno, Adv. Synth. Catal. 2006, 348, 101-110; c) J. GarcíaÁlvarez, J. Díez, J. Gimeno, C. M. Seifried, Chem. Commun. 2011, 47, 6470-6472.

[29] For a recent review article and a book on the chemistry of these species, see: a) S. V. Druzhinin, E. S. Balenkova, V. G. Nenajdenko, Tetrahedron 2007, 63, 7753-7808; b) V. G. Nenajdenko, S. V. Druzhinin, E. S. Balenkova, in Chemistry of $\alpha, \beta$-Unsaturated Trifluoromethyl Ketones, Nova Science Publishers, New York, 2007.

[30] These substrates can be easily accessed by addition of $\mathrm{CF}_{3} \mathrm{C} \equiv \mathrm{CLi}$, generated in situ from commercially available 2-bromo-3,3,3trifluoropropene and LDA, to the corresponding carbonyl compound. See, for example: a) A. R. Katritzky, M. Qi, A P. Wells, J. Fluorine Chem. 1996 $80,145-147$; b) N. Shinohara, J. Haga, T. Yamazaki, T. Kitazume, S. 
Nakamura, J. Org. Chem. 1995, 60, 4363-4374; c) Y. Watanabe, T. Yamazaki, J. Fluorine Chem. 2010, 131, 646-651.

[31] Redox-type isomerizations, i.e. not involving 1,3-shift of the hydroxy moiety, of $\mathrm{CF}_{3}$-containing secondary propargylic alcohols into enones have been recently described: Y. Watanabe, T. Yamazaki, J. Org. Chem 2011, 76, 1957-1960.

[32] Primary propargylic alcohols have proven to be very difficult substrates for the Meyer-Schuster reaction. In fact, only one successful methodology involving the combined use of $c i s-\left[\mathrm{MoO}_{2}(\mathrm{acac})_{2}\right]$
$\left[\mathrm{AuCl}\left(\mathrm{PPh}_{3}\right)\right]$ and $\mathrm{AgOTf}$ has been described to date in the literature. See reference $19 \mathrm{~b}$.

[33] M. M. Midland, J. Org. Chem. 1975, 40, 2250-2252.

[34] a) J. Suffert, D. Toussaint, J. Org. Chem. 1995, 60, 3550-3553; b) B. D. Sherry, A. T. Radosevich, F. D. Toste, J. Am. Chem. Soc. 2003, 125, 6076-6077.

Received: ((will be filled in by the editorial staff))

Published online: ((will be filled in by the editorial staff) 


\section{Entry for the Table of Contents}

\section{FULL PAPER}

A new protocol for the selective Meyer-Schuster rearrangement of propargylic alcohols has been developed using catalytic amounts of the readily accessible oxovanadate $(\mathrm{V})$ complex $\left[\mathrm{V}(\mathrm{O}) \mathrm{Cl}(\mathrm{OEt})_{2}\right]$.

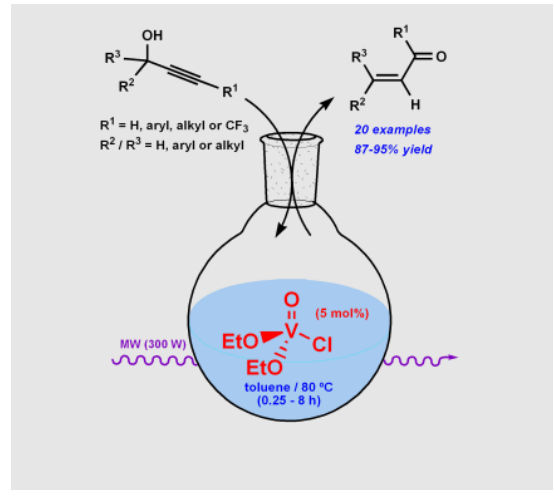

A. Antiñolo, F. Carrillo-Hermosilla * V. Cadierno, J. García-Álvarez, * A. Otero

Page No. - Page No.

MW-assisted Meyer-Schuster rearrangement of propargylic alcohols catalyzed by the oxovanadate complex $\left[\mathrm{V}(\mathrm{O}) \mathrm{Cl}(\mathrm{OEt})_{2}\right]$ 